\title{
Phenol and Mineral Content in Relation to Infection and Weight Loss by Botryodiplodia Botryodiplodia Theobromae Pat., in Market Samples of Colocasia Esculenta L.
}

\author{
Otusanya MO* \\ Department of Crop protection, Federal University of Agriculture Abeokuta, Nigeria
}

Received: 阱 July 12, 2018; Published: 阱 August 03, 2018

*Corresponding author: Otusanya MO, Department of Crop protection, College of Plant Science and Crop production, Federal University of Agriculture Abeokuta, Nigeria

\begin{abstract}
This study was carried out to relate infection and weight loss by Botryodiplodia theobromae Pat, in Colocasia esculenta L. corms with their phenol and/or calcium content. Corms were sourced from two major root and tuber markets in Osiele and Kila, in Odeda Local Government Area of Ogun State, Nigeria. The infection and weight loss experiment was in CRD (complete randomized design), with two treatments (the two markets) and seven replicates. Corms were inoculated with a 10-day old pure culture of B. theobromae and incubated for 10 days, after which infection and weight was determined. The infected corms were then analysed for phenol, calcium, nitrogen, phosphorus, potassium, magnesium, iron and sulphur content. Corms from Kila had infection and weight loss $41 \%$ and $37 \%$ respectively lower than corms from Osiele.

Phenol and calcium content of the corms from Kila were $89.20 \mathrm{mg} / 100 \mathrm{gdm}$ and $19.8 \mathrm{mg} / 100 \mathrm{gdm}$ respectively, significantly higher than those of the Osiele corms which were $81.59 \mathrm{mg} / 100 \mathrm{gdm}$ and $18.9 \mathrm{mg} / 100 \mathrm{gdm}$ respectively. High phenol with its antimicrobial activity as well as higher calcium conferring higher structural integrity against deterioration are adduced as the reason for lower infection and weight loss in the corms from Kila. The corms from Kila were also superior in terms of higher levels of six other nutrient minerals namely N, P, K, Mg, Fe and S which were 1281, $28.59,0.83,3.80,8.95$ and $888.5 \mathrm{mg} / 100 \mathrm{gdm}$ respectively, compared to $1249.5,27.93,0.81,2.98,8.81$ and $856 \mathrm{mg} / 100 \mathrm{gdm}$ in the Osiele corms. Tuber quality for storage and improvement of declining yield of Colocasia esculenta varieties in Nigeria is recommended with balanced mineral nutrition.
\end{abstract}

\section{Introduction}

Colocasia esculenta L (Cocoyam) may be referred to as an economic crop as all of the plant parts are put into use. It is cultivated for its edible corms, its leaves and flowers which are used in preparation of various indigenous foods and pharmaceuticals in Nigeria, Africa and Asia. It is rated third in ranks among staple tuber crops in Nigeria [1]. Microbial rots, weight loss and loss of viability in storage are major constraints to a long shelf life or preservation for the following planting season. Some of the major fungal rot pathogens of cocoyams in the South region of Nigeria are Aspergillus species, Botrodiplodia theobromae and Sclerotium rolfsii among others [1]. Low soil fertility and low yields disallow its use as a foreign exchange earner. Resource poor farmers who are involved in the bulk of cocoyam production in Nigeria lack the necessary management inputs such as fertilizers and, or fungicides in a sustainable way.

Proper/balanced nutrition of the crop in the field becomes a necessary tool to sidetrack difficulties of access to loans/capital for well-strategized management techniques or well improved storage facilities for the farmers. Mineral nutrition in a balanced manner though requiring sustained research on the long run is affordable for smallholders. This study was carried out to investigate mineral content and deterioration (infection and weight loss) in market samples of Colocasia esculenta corms. The specific objectives were to inoculate them with the cocoyam rot pathogen Botrydiplodia theobromae and determine infection and weight loss, as well as relate these to phenol and calcium content of the corms.

Materials and Methods

\section{Sourcing of Colocasia Esculenta Corms}

Colocasia esculenta corms for the study were sourced from the major root and tuber markets in Osiele and Kila in Odeda local government areas of Ogun State in the South West region of Nigeria.

\section{Infection and Weight Loss Experiment}

The infection and weight loss experiment was in complete randomized design, of two treatments (the sampled markets) and seven replicates. The inoculation experiment was carried out in an Inoculation Hood Structure in the Crop Protection Laboratory of the Department of Crop Protection, Federal University of Agriculture, Abeokuta. Corms were weighed with an electronic 
balance and then surface sterilized at the point to be inoculated by swabbing with cotton wool dipped in $80 \%$ ethanol. Two $4 \mathrm{~mm}$ diameter cork borers, scalpel and a pair of forceps were surfacesterilized by flaming until red-hot over a lighted spirit flame bottle, and then cooling them, slanted over another cork borer. Holes of about $15 \mathrm{~mm}$ were made through the surface-sterilized inoculation site of each corm, with the surface-sterilized $4 \mathrm{~mm}$ cork borer.

The cut tissue was lifted out with the scalpel and forceps. A $4 \mathrm{~mm}$ agar (potato dextrose agar) disc of a 10-day old pure culture of Botryodiplodia theobromae from a $9 \mathrm{~cm}$ petri-dish, was lifted out with the second sterile cork-borer and placed inside the hole in the corm. The cut-out tissue was then replaced, and the incision sealed with vaseline (petroleum jelly). The inoculated corms were put on surface-sterilized plastic trays. They were then transferred into raised wooden, netted yam storage structures (protected from rain) inside the COLPLANT (College of Plant Science and Crop Production) Screenhouse, in COLPLANT Building, Federal University of Agriculture (FUNAAB), Abeokuta, for a 10-day incubation period. After this the corms were weighed again. The vaseline on the corms was cleared away with spatula and cotton had been cut through the inoculation site with a knife, into a preweighed 9 -cm petri-dish. The infected tissue weight was measured with an electronic balance.

\section{Calculations of Infection and Weight Loss}

Percent infection was calculated with the formula: \% Infection $=(\mathrm{C} / \mathrm{A}) 100$, where $\mathrm{C}$ is corrected weight of infected tissue, and $\mathrm{A}$ is weight of corm at the beginning of the experiment. $\mathrm{C}$ is calculated from the formula $=100 \mathrm{X} /(100-\mathrm{Y})$, Where $\mathrm{x}=$ Weight of infected tissue and $Y=\%$ weight loss (Otusanya and Jeger, 1994). Percent weight loss was calculated with the formula:

$\%$ Weight loss=((A-B)/A)100, where $A$ and $B$ are weight of the corm at the beginning and at the end of the experiment respectively.

\section{Processing and Analysis of Phenol, Calcium and Other Minerals}

After the measurement of infected tissue, each corm with the infected portion, was cut into thin slices with a washed, surfacesterilized steel knife and spread on washed and dried labelled plastic trays. The trays were transferred to the top of raised wooden, wool. Infected tissue was cut away with a scalpel after the corm

yam storage structures (under shade) inside the COLPLANT screenhouse, for the drying of the sliced corms, for 2 to 3 days. After this, the dried slices were milled to powder with a National 4-speed Waring Blender, and poured into fresh labelled polythene bags for analysis. Analysis of phenol, calcium, magnesium, nitrogen, phosphorus, potassium, iron and sulphur was according to routine methods of the A.O.A.C. (1990). Analysis of the milled cocoyams was carried out at the Biotechnology Centre and the Biological Science Tetfund Laboratory, FUNAAB.

\section{Data Analysis}

Data were transformed appropriately before analysis of variance. Means were separated with Tukey's (HSD) test.

\section{Results}

\section{Infection and Weight Loss After Incubation of Corms with $B$. Theobromae for 10 Days}

Percent infection of $8.15 \%$ in cocoyams from Osiele was significantly higher than that of cocoyams from Kila, which was $5.12 \%$ (Table 1). Weight loss of $13.89 \%$ n Osiele cocoyams was also higher than that of the Kila cocoyams which was $8.16 \%$ (Table 1).

Table 1: Infection and weight loss in corms of Colocasia esculenta from Kila and Osiele markets after incubation with Botryodiplodia theobromae for 10 days.

\begin{tabular}{|c|c|c|}
\hline Source of C. esculenta & \% Infection & \% Weight loss \\
\hline Kila & $5.12 \mathrm{~b}$ & $8.16 \mathrm{~b}$ \\
\hline Osiele & $8.15 \mathrm{a}$ & $13.89 \mathrm{a}$ \\
\hline
\end{tabular}

Phenol Content, Calcium and Other Minerals in Corms After 10-Day Incubation with Botryodiplodia Theobromae

Phenol content of $89.20 \mathrm{mg} / 100 \mathrm{gdm}$, was higher in the infected corms from Kila than that of Osiele which had $81.59 \mathrm{mg} / 100 \mathrm{gdm}$ phenol content (Table 2). Calcium content of $19.80 \mathrm{mg} / 100 \mathrm{gdm}$ in the corms from Kila was also higher than that of corms from Osiele which had $18.9 \mathrm{mg} / 100 \mathrm{gdm}$. Magnesium, Potassium, Nitrogen, Sulphur, Phosphorus and Iron of the values 3.8, 0.83, 1281, 888.5, 28.59 and $8.95 \mathrm{mg} / 100 \mathrm{gdm}$ respectively were also higher in the corms from Kila than those of the Osiele corms which had 2.98, $0.81,1249.5,856,27.93$ and $8.81 \mathrm{mg} / 100 \mathrm{gdm}$ respectively (Table 2).

Table 2: Minerals and Phenol (mg/100g dry matter) in corms of Colocasia esculenta (Ce) from Kila and Osiele after incubation with Botryodiplodia theobromae for 10 days.

\begin{tabular}{|c|c|c|c|c|c|c|c|c|}
\hline Treatment & $\mathbf{C a}$ & $\mathbf{M g}$ & $\mathbf{K}$ & $\mathbf{N}$ & $\mathbf{S}$ & $\mathbf{P}$ & $\mathbf{F e}$ & Phenol \\
\hline & $\mathrm{mg} / 100 \mathrm{gdm}$ & $\mathrm{mg} / 100 \mathrm{gdm}$ & $\mathrm{mg} / 100 \mathrm{gdm}$ & $\mathrm{mg} / 100 \mathrm{gdm}$ & $\mathrm{mg} / 100 \mathrm{gdm}$ & $\mathrm{mg} / 100 \mathrm{gdm}$ & $\mathrm{mg} / 100 \mathrm{gdm}$ & $\mathrm{mg} / 100 \mathrm{gdm}$ \\
\hline Ce KILA+Bt & $19.80 \mathrm{a}$ & $3.80 \mathrm{a}$ & $0.83 \mathrm{a}$ & $1281.0 \mathrm{a}$ & $888.5 \mathrm{a}$ & $28.59 \mathrm{a}$ & $8.95 \mathrm{a}$ & $89.20 \mathrm{a}$ \\
\hline Ce OSIELE+ Bt & $18.90 \mathrm{~b}$ & $2.98 \mathrm{~b}$ & $0.81 \mathrm{~b}$ & $1249.5 \mathrm{~b}$ & $856.0 \mathrm{~b}$ & $27.93 \mathrm{~b}$ & $8.81 \mathrm{~b}$ & $81.59 \mathrm{~b}$ \\
\hline
\end{tabular}

\section{Discussion}

Average infection and weight loss of $6.64 \%$ and $11.03 \%$ respectively in only 10 days of incubation with Botryodiplodia theobromae, an important cocoyam rot pathogen is high and warrants research attention. This is the reason why cocoyam corms are not kept for long on the shelf before consumption in Nigeria. Infection and weight loss in the 10-day incubation with Botryodiplodia theobromae in the corms from Kila, were $63 \%$ and 59\% respectively of that in the corms from Osiele. Analysis of phenol and calcium content indicated higher values of both in Kila corms than the Osiele corms. Phenol or phenolics present naturally 
or induced by microbial attack, increase resistance to infection and weight loss in Crop plants [2,3]. The phenolic compound B-sitosterol in the periderm of Dioscorea alata inhibited growth of Botryodiplodia theobromae [4]. Calcium on the other hand is involved in structural integrity of cells by formation of calcium pectate conferring this in the cell wall.

Generally, corms from Kila were superior in higher content of all the seven minerals namely $\mathrm{Ca}, \mathrm{Mg}, \mathrm{N}, \mathrm{P}, \mathrm{K}, \mathrm{S}$ and $\mathrm{Fe}$ than the Osiele corms. Mineral nutrients usage as an alternative to pesticides which pose concerns about environmental quality and pathogen resistance is being manipulated in recent times to control crop diseases [5]. This involves macronutrients needed in relatively higher quantities and micronutrients required in lower quantities. Cocoyams may be considered an economy or food security crop as the corms, cormels and leaves are useful for human consumption and other plant parts as animal feed [6]. The higher calcium and phenol content as well as other minerals in the corms from Kila is responsible for the higher resistance to infection/weight loss than the corms from Osiele [7-10]. These results focus research attention on the fact that balanced mineral nutrition is necessary to upgrade varietal quality and improve cocoyam production in South West Nigeria and in Nigeria also.

\section{References}

1. Onuegbu BA (1999) Composition of four cocoyam cultivars and their tolerance to corm rot. Tropical Sci 39(3): 136-139.

\section{ISSN: 2574-1241}

DOI: $10.26717 / B J S T R .2018 .07 .001530$

Otusanya MO. Biomed J Sci \& Tech Res

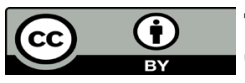

This work is licensed under Creative Commons Attribution 4.0 License

Submission Link: https://biomedres.us/submit-manuscript.php
2. Dube HC (2014) Modern Plant Pathology Second Edition. Published by Saraswati Purohit for Student Edition, Jodhpur pp. 576.

3. Singh RS (2002) Introduction to Principles of Plant Pathology. Oxford \& IBH Publishing Company, India pp 402.

4. Aderiye BI, Ogundana SK, Adesanya SA, Roberts MF (1989) The effect of $\beta$-sitosterol on spore germination and germ-tube elongation of Aspergillus niger and Botryodiplodia theobromae. International Journal of Food Microbiology 8(1): 73-78.

5. Dordas C (2008) Role of nutrients in controlling plant diseases in sustainable agriculture: A review. Agronomy for Sustainable Development 28(1): 33-46.

6. Pinto FJ, Onwueme JB (2000) Food values of breadfruit, taro leaves, coconut and sugar cane. FAO Plant Production and Protection Paper 126, FAO, Rome.

7. Arene OB, Ene, LSO (1987) Advances in cocoyam research at National Root Crops Research Institute Umudike (1972-1986) Proc. First National Workshop in Cocoyam, NRCRI, Umudike, Nigeria 58-71.

8. Eze CS, Maduewesi JNC (1990) Relation of Traditional Methods of Storage to the Magnitude of Storage Losses of Cocoyam [(Colocasia esculenta (L.) Schott. Nig Jour of Plant prot 13: 72-80.

9. Onwueme IC (1999) Taro cultivation in Asia and the Pacific. Food and Agriculture Organization of the United Nations, Regional Office for Asia \& the Pacific, RAP Publication No. 16. Bangkok, Thailand p. 50.

10. Otusanya MO, Jeger MJ (1994) Infection of Yam Tubers by Aspergillus niger in relation to Isolate, Yam Species and Temperatures. International Biodeterioration and Biodegradation 33(4): 319-331.

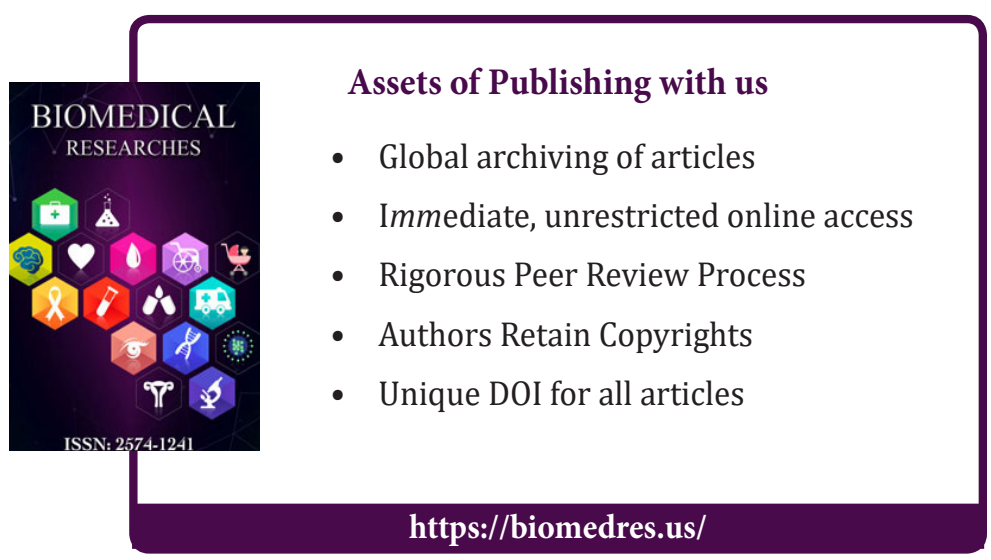

Cite this article: Otusanya MO. Phenol and Mineral Content in Relation to Infection and Weight Loss by Botryodiplodia Botryodiplodia 